\title{
ANALISIS PENGARUH STRATEGI BAURAN PEMASARAN TERHADAP MINAT BERKUNJUNG KEMBALI PADA DESTINASI WISATA PANTAI CAROCOK PAINAN KABUPATEN PESISIR SELATAN (STUDI KASUS PADA WISATAWAN DOMESTIK)
}

\author{
Yofina Mulyati, Miko Afrinata \\ Universitas Dharma Andalas \\ Fakultas Ekonomi dan Bisnis \\ Jl. Sawahan No. 103 A, Simpang Haru Padang \\ email: Yofina_Mulyati@yahoo.com
}

\begin{abstract}
Abstrak
Penelitian ini bertujuan untuk mengetahui pengaruh strategi bauran pemasaran terhadap minat berkunjung kembali di objek wisata Pantai Carocok Painan Kabupaten Pesisir Selatan (studi kasus pada wisatawan domestik). Penelitian ini menggunakan variabel bebas (X) yaitu Produk (X1), Harga (X2), Promosi (X3), Tempat (X4), Orang (X5), Proses (X6) dan Bukti Fisik (X7), serta variabel terikat (Y) yaitu Minat Berkunjung Kembali (Y). Populasi adalah semua wisatawan domestik yang berkunjung ke objek wisata pantai Carocok Painan. Teknik pengambilan sampel purpossive sampling dengan jumlah sampel sebanyak 150 responden. Metode analisis data yang digunakan adalah analisis regresi linear berganda. Hasil yang didapat dari penelitian ini menunjukkan secara persial variabel produk, promosi, lokasi dan bukti fisik berpengaruh positif dan signifikan terhadap Minat Berkunjung Kembali. Sedangkan variabel harga dan proses berpengaruh negatif tidak signifikan terhadap Minat Berkunjung Kembali. Sementara variabel Orang berpengaruh positif tidak signifikan terhadap Minat Berkunjung Kembali. Kemudian variabel Produk, Harga, Promosi, Lokasi, Orang, Proses, dan Bukti Fisik secara simultan mempunyai pengaruh positif signifikan terhadap Minat Berkunjung Kembali.
\end{abstract}

Kata Kunci: Bauran Pemasaran, Minat Berkunjung kembali

\section{Abstract}

This study aims to determine the effect of marketing mix strategy on the interest of visiting again at the beach attraction Carocok Painan Pesisir Selatan district (case studies on domestic tourists). This research using independent variable is Marketing mix consisting of Product $\left(X_{1}\right)$, Price $\left(X_{2}\right)$, Promotion $\left(X_{3}\right)$, Place $\left(X_{4}\right)$, Person $\left(X_{5}\right)$, Process $\left(X_{6}\right)$ and Physical Evidence $\left(X_{7}\right)$, and dependent variable $(Y)$ ie interest of visiting again $(Y)$. The population is all domestic tourists who visit the beach attractions Carocok Painan. The sampling technique was purposive sampling with 150 respondents. The data were collected by using questionnaires. Further data obtained were analyzed by using data analysis quantitatively and qualitatively. Quantitative analysis includes: validity and reliability test, classical assumption test, multiple regression analysis, hypothesis testing through t test and $F$ test, and coefficient of determination analysis $\left(R^{2}\right)$. The results of this study show that product, promotion, location and physical evidence variables have a positive and significant effect on Visiting Interest again. While the price and process variables have a negative effect are not significant to visiting interest again. While Person variable has a positive effect are not significant to Visiting Interest again. Then the Product, Price, Promotion, Location, Person, Process, and Physical Evidence variable simultaneously have a significant positive effect on Visiting Interest again.

Keywords: Marketing Mix, Visiting Interest again

\section{Pendahuluan}

Pariwisata merupakan salah satu sektor yang sangat diandalkan pemerintah sebagai penyumbang devisa dari penghasilan non migas di samping juga dapat menciptakan dan memperluas lapangan usaha juga dapat mendorong pembangunan daerah, memperkaya kebudayaan nasional dengan tetap melestarikan kepribadian bangsa dan terpeliharanya nilai-nilai agama sebagai karakteristik warga negara Indonesia. 
Sumatera Barat sebagai salah satu destinasi wisata di Indonesia dapat menjadi pilihan bagi para wisatawan untuk berlibur akhir pekan. Berbagai obyek wisata alam dan budaya terdapat di provinsi yang terkenal dengan ciri khas arsitektur Rumah Gadang ini.

Salah satu sektor pariwisata di Sumatera Barat yang memiliki potensi untuk dikembangkan menjadi wisata unggulan adalah wisata pantai. Pantai Carocok Painan adalah salah satu objek wisata yang memiliki keunikan dan keindahan tersendiri. Pantai Carocok menjadi magnet wisata yang tak pernah sepi dikunjungi. Pantai yang membentang antara Painan di Kabupaten Pesisir Selatan dan Kota Padang ini tak pernah berhenti berbenah, menambah berbagai fasilitas untuk memanjakan para wisatawan. Di kawasan pantai ini, pengunjung tidak hanya disuguhi dengan keindahan pantai yang memukau namun juga panorama bawah laut yang mempesona, ditambah cerita sejarah yang sayang untuk dilewatkan. Banyak orang yang membandingkan Carocok dengan Pantai Sanur di Bali atau Pantai Semenjung Kra di Malaysia, hal itu tidaklah berlebihan karena pantai ini tidaklah berlebihan karena pantai ini tidak kalah cantik dengan dua pantai terkenal itu.

Berikut ini disajikan data jumlah pengunjung wisatawan domestik ke Pantai Carocok periode tahun 2011-2015.

Tabel 1

Jumlah Pengunjung Wisatawan Domestik ke Pantai Carocok

Periode Tahun 2011-2015

(Dalam Orang)

\begin{tabular}{ccc}
\hline Tahun & $\begin{array}{c}\text { Wisatawan Domestik } \\
\text { (Dalam Orang) }\end{array}$ & $\begin{array}{c}\text { Pertumbuhan / } \\
\text { Tahun }(\%)\end{array}$ \\
\hline 2011 & 116.127 & \\
2012 & 306.670 & 164,1 \\
2013 & 587.056 & 91,4 \\
2014 & 1.544 .684 & 163,1 \\
2015 & 2.000 .000 & 29,5 \\
\hline
\end{tabular}

Sumber : Badan Pusat Statistik Kabupaten Pesisir Selatan tahun 2016

Berdasarkan data pada tabel 1.1 yang diperoleh dari Badan Pusat Statistik Kabupaten Pesisir Selatan tahun 2015, memperlihatkan bahwa dalam lima tahun terakhir $(2011$ - 2015) terlihat adanya peningkatan jumlah pengunjung di objek wisata Carocok Painan yang cukup signifikan. Hal ini dikarenakan adanya berbagai event yang diselenggarakan pemerintahan daerah Pesisir Selatan setiap tahunnya, seperti perlombaanperlombaan dan festival kebudayaan yang ditujukan untuk mendorong minat wisatawan berkunjung ke pantai Carocok. Namun pada tahun 2015 peningkatannya tidak sebesar pada tahun sebelumnya yang meningkat sebesar 163,1\%. Meningkatnya jumlah wisatawan domestik berkunjung ke pantai Carocok Painan tentunya perlu diimbangi dengan peningkatan infrastruktur dan fasilitas pendukung lainnya seperti peningkatan akses jalan menuju lokasi objek wisata, atraksi wisata, transportasi serta tersedianya rumah makan dan akomodasi. Namun kenyataannya banyak diantara pengunjung yang merasa kecewa setelah berkunjung ke objek wisata carocok. Beberapa keluhan mereka antara lain tidak tersedianya rumah makan dan penginapan yang memadai, tempat parkir yang kurang nyaman, tempat ibadah yang kurang memadai, dan tidak tersedianya toilet yang bersih disamping juga masih kurangnya transportasi umum yang beroperasi disekitar pantai Carocok Painan.

Hasil pra survei yang dilakukan pada tanggal 14 Mei 2017 terhadap 30 wisatawan domestik di pantai Carocok Painan Kabupaten Pesisir Selatan, 13 orang wisatawan domestik $(43 \%)$ menyatakan puas dengan apa yang didapatkan dipantai Carocok Painan, dengan alasan pantai Carocok Painan punya banyak pilihan wahana permainan, biaya perjalanan relatif murah, keindahan pantai dan fasilitas pendukung lainya yang tidak dimiliki oleh wisata pantai lainnya yang ada di Sumatera Barat. Sedangkan $56 \%$ atau 17 orang dari 30 wisatawan domestik yang disurvei menyatakan tidak puas dengan objek wisata Pantai Carocok Painan dengan alasan kebersihan pantai kurang terjaga, lapangan parkir yang belum tertata rapi dan akses menuju lokasi objek wisata hanya bisa dicapai dengan kendaraan pribadi dan mobil yang disewa atau carteran sedangkan transportasi umum masih terbatas jumlahnya. Selanjutnya dari 30 orang wisatawan 10 orang $(33 \%)$ menyatakan tidak ingin kembali berkunjung ke pantai Carocok dengan alasan bahwa informasi yang mereka peroleh tentang objek wisata Carocok dengan berbagai produk wisata dan fasilitas yang tersedia disana tidak sesuai dengan apa yang mereka rasakan ketika berkunjung. Ketidakpuasan yang dirasakan pengunjung akan mempengaruhi minat wisatawan untuk berkunjung kembali. Dengan demikian dapat disimpulkan bahwa strategi pemasaran yang telah dilakukan oleh pemerintah daerah Pesisir Selatan belum sepenuhnya mampu menarik minat wisatawan untuk berkunjung kembali ke objek wisata pantai Carocok.

Menurut Tjiptono (2008), bauran pemasaran merupakan seperangkat alat yang dapat digunakan pemasar untuk membentuk karateristik jasa yang ditawarkan kepada pelangan, yang meliputi produk, harga, tempat dan promosi. Dalam pemasaran jasa, ada elemen-elemen lain yang bisa dikontrol dan bisa dikombinasikan untuk keperluan komunikasi dengan konsumen jasa. Lupiyadi, (2013) menyatakan bahwa elemen tersebut adalah: orang (people), lingkungan fisik (physical evidence) dan proses jasa itu sendiri (process). Dengan demikian $4 \mathrm{P}$ yang pada mulanya menjadi bauran pemasaran, 
perlu diperluaskan menjadi 7P jika digunakan dalam pemasaran jasa.

Beberapa penelitian dilakukan untuk membuktikan mengenai teori bauran pemasaran dalam meningkatkan penjualan ataupun jasa objek wisata. Ada penelitian yang menunjukkan bahwa teori strategi bauran pemasaran dapat diterapkan dengan baik, tetapi ada juga yang tidak sesuai dengan keadaan yang terjadi di lapangan. Penelitian yang dilakukan Rambe (2014) Terhadap Minat Berkunjung Kembali ke Wonders Water World Waterpark CBD Polonia Medan memperlihatkan bahwa secara simultan, produk, promosi, harga dan proses berpengaruh secara positif tetapi tidak signifikan terhadap minat berkunjung kembali. Secara parsial, produk, promosi, harga dan proses berpengaruh positif terhadap minat berkunjung kembali tetapi tidak signifikan. Variabel yang dominan pada penelitian ini adalah proses sedangkan variabel lokasi, orang dan bukti fisik berpengaruh negatif dan tidak signifikan terhadap minat berkunjung kembali. Sedangkan Bachtiar (2016), dalam penelitianya yang berjudul "Pengaruh Strategi Bauran Pemasaran Terhadap Minat Berkunjung Kembali di Objek Wisata Pantai Gunung Kidul" penelitian tersebut menemukan bahwa variabel produk, harga, promosi, lokasi, orang, proses dan bukti fisik secara simultan berpengaruh positif terhadap minat berkunjung kembali.

Dari penelitian tersebut dapat di simpulkan bahwa bauran pemasaran belum sepenuhnya memberikan pengaruh positif terhadap minat berkunjung kembali. Ada penelitian menggunakan tujuh variabel marketing mix memberikan pengaruh positif signifikan terhadap minat berkunjung kembali, sebaliknya pada objek wisata Wonders Water Word Waterpark CBD Polinia Medan dimana variabel produk, promosi, harga dan proses berpengaruh positif tetapi tidak signifikan terhadap minat berkunjung kembali sedangkan variabel lokasi, orang dan bukti fisik berpengaruh negatif dan tidak signifikan terhadap minat berkunjung kembali. Oleh karena itu, penulis mencoba membuat penelitian tentang pengaruh bauran pemasaran dan serta pengaruhnya terhadap minat berkunjung kembali pada objek wisata yang baru yaitu objek wisata pantai Carocok Painan Kabupaten Pesisir Selatan. Pemilihan objek wisata pantai Carocok Painan Kabupaten Pesisir Selatan dengan alasan karena animo atau antusias wisatawan domestik terhadap objek wisata pantai Carocok Painan Kabupaten Pesisir Selatan saat ini yang terus meningkat.

\section{KERANGKA TEORI}

Jahja (2011) menyatakan, minat adalah suatu dorongan yang mengakibatkan terikatnya perhatian individu pada objek tertentu seperti pekerjaan, pelajaran, benda dan orang. Sedangkan minat berkunjung kembali merupakan prilaku yang muncul sebagai respon terhadap objek yang menunjukkan keinginan pelanggan untuk melakukan kunjungan ulang (Umar (2004).

Menurut Tjiptono (2005), bauran pemasaran merupakan seperangkat alat yang dapat digunakan pemasar untuk membentuk karateristik jasa yang ditawarkan kepada pelangan. Alat-alat tersebut dapat digunakan untuk menyusun strategi jangka panjang dan merancang program taktik jangka pendek. Selanjutnya Buchari alma (2007) menyatakan, ada empet komponen yang tercakup dalam kegiatan marketing mix ini yang terkenal dengan sebutan 4P yang terdiri dari: product, price, place, dan promosi. Dalam perkembangan sejumlah penelitian menunjukan bahwa penerapan 4P terlampau sempit/terbatas untuk bisnis jasa. Kelemahan yang terdapat pada 4P, mondorong banyak pakar pemasaran untuk mendefenisikan ulang bauran pemasaran sedemikian rupa sehingga lebih aplikatif untuk sektor jasa. Hasilnya 4P tradisional diperluas dan ditambahkan dengan unsur lainnya, yaitu People, Proces, Physical Evidence dan Custamer Service. Selanjutnya Alma (2007) menyatakan bauran pemasaran jasa terdiri dari: Produk, Promosi, Harga, Lokasi, Orang, Bukti Fisik dan Proses.

Menurut Suwantoro (2007) produk wisata adalah keseluruhan pelayanan yang diperoleh dan dirasakan atau dinikmati wisatawan semenjak ia meninggalkan tempat tinggalnya sampai ke daerah tujuan wisata yang dipilihnya dan sampai kembali ke rumah dimana ia berangkat semula.

Menurut Bukart dan Medlik dalam Yoeti (2004) mendiskripsikan produk wisata sebagai susunan produk yang terpadu, yang terdiri dari obyek wisata, atraksi wisata, transportasi (jasa angkutan), akomodasi dan hiburan di mana tiap unsur dipersiapkan oleh masing-masing perusahaan dan ditawarkan secara terpisah.

Dalam penelitian ini digunakan dua indikator produk wisata yang diadaptasi dari Purnama dan Murwatiningsih (2014) yaitu: (a) Fasilitas tujuan wisata, (b) Daya tarik wisata.

Engel (2004) mendefinisikan harga sebagai sejumlah uang (ditambah beberapa produk) yang dibutuhkan untuk mendapatkan sejumlah kombinasi dari produk dan pelayanannya. Harga mempunyai pengaruh yang positif dengan kualitas, semakin tinggi harga akan mencerminkan kualitas yang semakin baik. Dalam penelitian ini digunakan dua indikator harga yang diadaptasi dari Stanton (1996) dalam Laksana (2008) yaitu:

a. Keterjangkauan harga

b. Kesesuaian harga dengan kualitas produk.

c. Kesesuaian harga dengan manfaat.

Menurut Laksana (2008), promosi adalah suatu komunikasi dari penjual dan pembeli yang berasal dari informasi-informasi yang tepat yang bertujuan 
untuk merubah sikap dan tingkah laku pembeli, yang tadinya tidak mengenal menjadi mengenal sehingga menjadi pembeli dan tetap mengingat produk tersebut. Sedangkan Tjiptono (2008) menyatakan bahwa promosi adalah semua kegiatan yang dimaksudkan untuk menyampaikan atau mengkomunikasikan suatu produk kepada pasar sasaran, untuk memberikan informasi tentang keistimewaan suatu produk. Kegunaan yang paling penting adalah tentang keberadaannya, untuk mengubah sikap ataupun untuk mendorong orangorang supaya bertindak.

Dalam penelitian ini digunakan tiga indikator lokasi yang diadaptasi dari Tjiptono, dkk (2005) dalam Syafitri (2012) yaitu: Aksesibilitas, Visibilitas dan Tempat parker

Menurut Zeithaml and Bitner (2003), "people is all human actors who pay in service delivery and thus influence the buyer's perceptions; namely, the firm's personnel, the customer and other customers in the service environment." People (orang) adalah semua pelaku yang memainkan peranan dalam penyajian jasa sehingga dapat mempengaruhi persepsi pembeli. Dalam penelitian ini digunakan tiga indikator people yang diadaptasi dari Bilson (2001)

a. Kompetensi
b. Kesopanan
c. Komunikasi
Proses menurut Zeithaml and Bitner (2000) adalah "The actual procedures, mechanism, and flow of activities by which the service is delivered the service delivery and operating system". Dalam penelitian ini digunakan tiga indikator proses yang diadaptasi dari Purnama dan Murwatiningsih (2014)

a. Kecepatan proses pembelian tiket

b. Penyampaian terhadap keluhan

c. Layanan yang diberikan cukup baik

Menurut Zeithaml and Bitner yang dikutip oleh Ratih Hurriyati (2005) pengertian physical evidence (bukti fisik) merupakan suatu hal yang turut mempengaruhi keputusan konsumen untuk membeli dan menggunakan produk jasa yang di tawarkan. Dalam penelitian ini digunakan tiga indikator bukti fisik yang diadaptasi dari Rukmi, dkk (2013)
a. Lingkungan
b. Tata letak
c. Fasilitas tambahan

\section{Kerangka Pemikiran}

Berdasarkan landasan teori dan penelitian terdahulu maka dapat disusun suatu kerangka pemikiran penelitian seperti yang disajikan dalam gambar berikut :

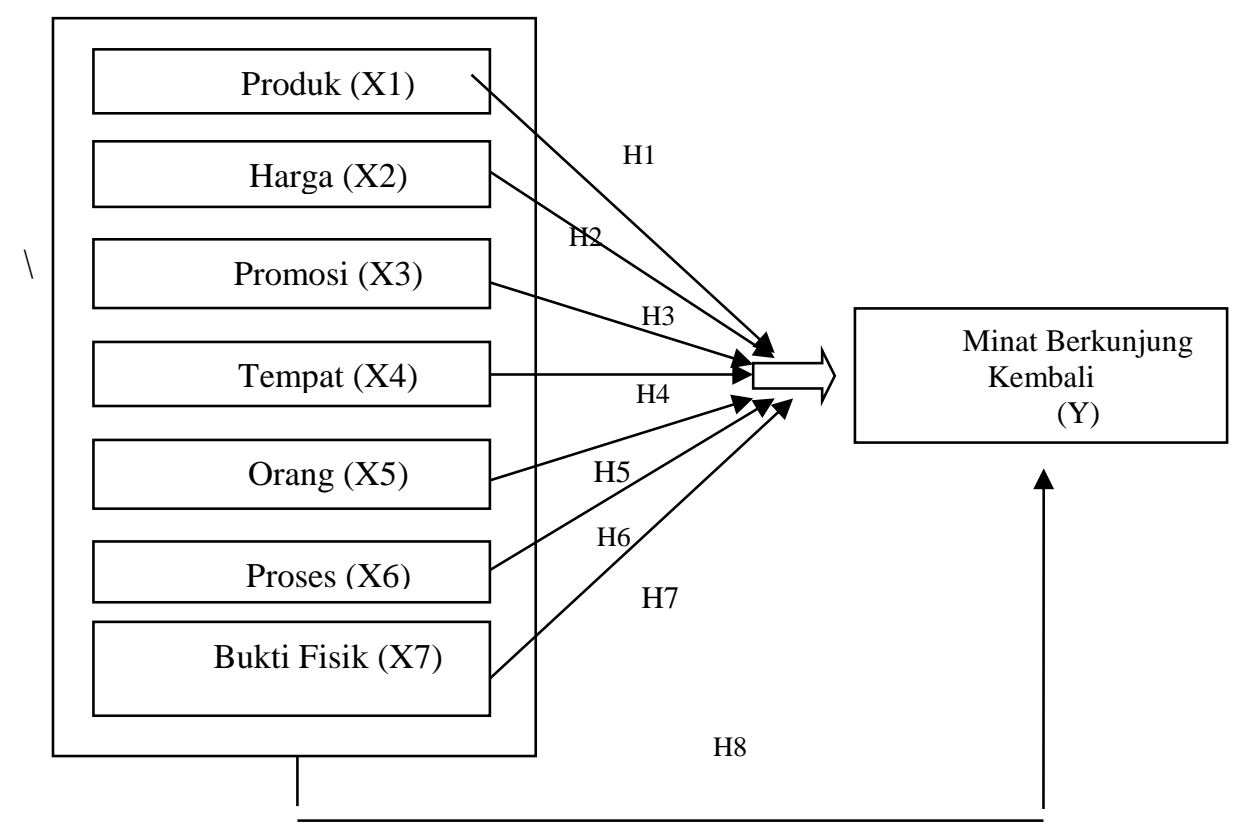

Gambar 1 Model Penelitian

\section{Metode Penelitian}

\subsection{Jenis Penelitian}

Penelitian ini merupakan penelitian deskriptif kuantitatif yang bertujuan untuk menjelaskan suatu fenomena empirisnya yang disertai data statistik, karateristik dan pola hubungan antar variabel.

\subsection{Populasi dan Sampel}

Populasi dalam penelitian. ini adalah wisatawan domestik yang berkunjung ke objek wisata pantai Carocok Painan. Hair, dkk (2006) 
menyatakan, ukuran sampel sebaiknya jumlah indikator pada variabel dikalikan 5-10. Pada penelitian ini terdapat 28 item pertanyaan, dengan demikian sampel dalam penelitian berkisar antara 140-280 responden, sampel yang diambil sebanyak 150 responden. Metode pengambilan sampel secara non probabilitas berupa purposive sampling. Purposive sampling dilakukan dengan mengambil sampel dari populasi berdasarkan kriteria yang ditentukan oleh peneliti. Adapun kriteria smpel sebagai berikut :

a) Wisatawan domestik yang pernah mengunjungi wisata pantai Carocok Painan.

b) Frekuensi berkunjung lebih dari dua kali

c) Periode kunjungan terakhir dilakukan dalam kurun waktu dua tahun terakhir (2015-2016)

\subsection{Metode Analisis Data}

Metode analisis data meliputi uji validitas dan reliabilitas, kemudian uji asumsi klasik yang terdiri dari uji normalitas, Uji Multikolinearitas, Uji Heteroskedastisitas serta metode analisa data yang dipergunakan adalah analisis Regresi Berganda, sementara untuk uji hipotesis terdiri dari Uji Parsial
(Uji t) serta Uji Signifikasi Simultan (Uji F) dan juga melihat hasil uji Koefisien Determinasi $\left(\mathrm{R}^{2}\right)$.

\section{Pembahasan}

\subsection{Profil Responden}

Berdasarkan hasil pentabulasian data dapat disimpulkan dari 150 responden, paling banyak didominasi oleh perempuan yaitu sebanyak 101 orang (67\%), sedangkan responden laki-laki berjumlah 49 orang (33\%). Sementara dari usia responden yang banyak ditemui dalam penelitian ini adalah yang berusia antara $18-25$ tahun yaitu sebanyak 116 orang (77\%), kemudian pada umumya responden berpendidikan terakhir SMA yaitu sebanyak 113 orang (75\%), dengan pekerjaan terbanyak sebagai Pelajar/mahasiswa yaitu sebanyak 110 orang (73\%) dari keseluruhan responden.

\subsection{Analisis Regresi Linier Berganda}

Dalam penelitian ini, analisis regresi linier berganda adalah sebagai berikut :

Tabel 1

Analisis Regresi Linier Berganda dan Uji Parsial (t)

\begin{tabular}{|c|c|c|c|c|c|c|c|}
\hline \multicolumn{8}{|c|}{ Coefficients $^{\mathrm{a}}$} \\
\hline \multirow{2}{*}{ Model } & \multicolumn{2}{|c|}{$\begin{array}{l}\text { Unstandardized } \\
\text { Coefficients }\end{array}$} & $\begin{array}{l}\text { Standardized } \\
\text { Coefficients }\end{array}$ & \multirow[t]{2}{*}{$\mathrm{T}$} & \multirow{2}{*}{ Sig. } & \multicolumn{2}{|c|}{$\begin{array}{l}\text { Collinearity } \\
\text { Statistics }\end{array}$} \\
\hline & B & Std. Error & Beta & & & Tolerance & VIF \\
\hline (Constant) & .621 & .610 & & 1.017 & .311 & & \\
\hline Produk & .322 & .097 & .259 & 3.322 & .001 & 0.613 & 1.630 \\
\hline Harga & -.073 & .101 & -.047 & -.716 & .475 & 0.876 & 1.142 \\
\hline Promosi & .297 & .087 & .415 & 4.587 & .000 & 0.453 & 2.208 \\
\hline Lokasi & .192 & .095 & .153 & 2.012 & .046 & 0.641 & 1.560 \\
\hline Orang & .166 & .116 & .133 & 1.424 & .157 & 0.425 & 2.354 \\
\hline Proses & -.161 & .135 & -.086 & -1.193 & .235 & 0.720 & 1.388 \\
\hline Bukti_Fisik & .439 & .082 & .034 & .477 & .034 & 0.750 & 1.333 \\
\hline
\end{tabular}

\subsection{Uji Hipotesis}

\subsubsection{Uji Hipotesis Secara Parsial (Uji t)}

Dalam penelitian ini, hasil uji parsial (uji t) dapat dilihat pada tabel 1. Berdasarkan tabel diatas menunjukkan bahwa uji hipotesis secara parsial adalah sebagai berikut :

1. Variabel produk menunjukkan uji hipotesis secara parsial ialah $\mathrm{H} 0$ ditolak dan menerima $\mathrm{Ha}$, hal ini dikarenakan nilai signifikansi $(0.001<$ 0.05). Maka dapat dikatakan variabel produk berpengaruh positif signifikan terhadap minat berkunjung kembali

2. Variabel harga menunjukkan uji hipotesis secara parsial ialah $\mathrm{H} 0$ diterima dan menolak $\mathrm{Ha}$, hal ini dikarenakan nilai signifikansi (0.475> 0.05). Maka dapat dikatakan variabel harga berpengaruh negatif tidak signifikan terhadap minat berkunjung kembali

3. Variabel promosi menunjukkan uji hipotesis secara parsial ialah $\mathrm{H} 0$ ditolak dan menerima Ha, hal ini dikarenakan nilai signifikansi $(0.000<$ 0.05). Maka dapat dikatakan variabel promosi berpengaruh positif signifikan terhadap minat berkunjung kembali.

4. Variabel lokasi menunjukkan uji hipotesis secara parsial ialah $\mathrm{H} 0$ ditolak dan menerima $\mathrm{Ha}$, hal ini dikarenakan nilai signifikansi $(0.046<0.05)$. Maka dapat dikatakan variabel lokasi berpengaruh positif signifikan terhadap minat berkunjung kembali.

5. Variabel orang menunjukkan uji hipotesis secara parsial ialah $\mathrm{H} 0$ diterima dan menolak $\mathrm{Ha}$, hal ini 
dikarenakan nilai signifikansi $(0.157>0.05)$. Maka dapat dikatakan variabel orang berpengaruh positif tidak signifikan terhadap minat berkunjung kembali.

6. Variabel proses menunjukkan uji hipotesis secara parsial ialah $\mathrm{H} 0$ diterima dan menolak Ha, hal ini dikarenakan nilai signifikansi (0.235> 0.05). Maka dapat dikatakan variabel proses berpengaruh negatif tidak signifikan terhadap minat berkunjung kembali.

7. Variabel bukti fisik menunjukkan uji hipotesis secara parsial ialah $\mathrm{H} 0$ ditolak dan menerima Ha, hal ini dikarenakan nilai signifikansi (0.034>
0.05). Maka dapat dikatakan variabel bukti fisik berpengaruh positif signifikan terhadap minat berkunjung kembali.

\subsubsection{Uji Hipotesis Secara Simultan (Uji f)}

Uji statistik F pada dasarnya menunjukkan apakah semua variabel independen yang dimasukkan dalam model mempunyai pengaruh secara bersama-sama atau simultan terhadap variabel dependen (Ghozali, 2009). Dalam penelitian ini, hasil uji simultan (uji f) adalah sebagai berikut :

Tabel 2

Uji Simultan

ANOVA $^{b}$

\begin{tabular}{llrrrrr}
\hline \multicolumn{2}{l}{ Model } & \multicolumn{2}{c}{ Sum of } & & & \\
Squares & Df & Mean Square & F & Sig. \\
\hline \multirow{2}{*}{1} & Regression & 35.199 & 7 & 5.028 & 18.159 & $.000^{\mathrm{a}}$ \\
& Residual & 39.321 & 142 & .277 & & \\
& Total & 74.519 & 149 & & & \\
\hline
\end{tabular}

Sumber Data : Olahan SPSS 2017

Dari tabel 2 terlihat bahwa hasil pengujian hipotesis Produk, Harga, Promosi, Lokasi, Orang, Proses, dan Bukti Fisik terhadap Minat wisatawan untuk berkunjung kembali menunjukkan nilai $\mathrm{f}$ hitung sebesar 18.159 dengan taraf signifikansi $0.000<0.05$ sehingga Ho ditolak dan Ha diterima. Dengan demikian dapat berarti bahwa Produk, Harga, Promosi, Lokasi, Orang, Proses, dan Bukti Fisik secara bersama mempunyai pengaruh positif terhadap Minat Berkunjung kembali.

\subsubsection{Uji Koefisien Determinasi $\left(R^{2}\right)$}

Pada dasarnya uji ini mengukur sejauh mana kemampuan model dalam menerangkan variasi variabel dependen. Nilai koefisien determinasi adalah antara nol dan satu (Ghozali, 2009). Nugroho (2005), menyatakan untuk regresi linear berganda sebaiknya menggunakan $\mathrm{R}$ square yang sudah disesuaikan atau tertulis Adjusted $R$ square untuk melihat koefisien determinasi, karena disesuaikan dengan jumlah variabel independen yang digunakan, dimana jika variabel independen 1 (satu) maka menggunakan $R$ square dan jika telah melebihi 1 (satu) menggunakan adjusted $R$ square. Hasil uji koefisien determinasi dalam penelitian ini adalah sebagai berikut :

Tabel 3

Analisis Koefisien Determinasi

Model Summary ${ }^{\mathbf{b}}$

\begin{tabular}{|c|c|c|c|c|c|c|c|c|c|c|}
\hline \multirow[b]{2}{*}{ Model } & \multirow[b]{2}{*}{$\mathrm{R}$} & \multirow[b]{2}{*}{ R Square } & \multirow[b]{2}{*}{$\begin{array}{l}\text { Adjusted } \\
\text { R Square }\end{array}$} & \multirow[b]{2}{*}{$\begin{array}{l}\text { Std. Error of } \\
\text { the Estimate }\end{array}$} & \multicolumn{5}{|c|}{ Change Statistics } & \multirow[b]{2}{*}{$\begin{array}{l}\text { - Durbin- } \\
\text { Watson }\end{array}$} \\
\hline & & & & & $\begin{array}{l}\text { R Square } \\
\text { Change }\end{array}$ & F Change & df1 & $\mathrm{df} 2$ & $\begin{array}{c}\text { Sig. F } \\
\text { Change }\end{array}$ & \\
\hline 1 & $.687^{\mathrm{a}}$ & .472 & .446 & .52622 & .472 & 18.159 & 7 & 142 & .000 & 1.222 \\
\hline
\end{tabular}

Sumber Data : Olahan SPSS 2017

Berdasarkan tabel 3 dapat diketahui nilai koefisien korelasi linear adalah 0.687, artinya menunjukkan hubungan yang kuat antara variabel independen, yaitu Produk, Harga, Promosi, Lokasi, Orang, Proses, dan Bukti Fisik terhadap Minat Berkunjung kembali.

Selanjutnya nilai koefisien determinasi (adjusted $R$ square) adalah sebesar 0,446 hal ini berarti 44,6\% Produk, Harga, Promosi, Lokasi,
Orang, Proses, dan Bukti Fisik bisa menjelaskan minat berkunjung kembali di objek wisata Pantai Carocok Painan, sedangkan sisanya sebesar 55,2\% dijelaskan oleh faktor-faktor lain yang tidak diteliti dalam penelitian ini.

\subsection{Pembahasan Pengaruh Produk terhadap Minat Berkunjung Kembali Secara Parsial}


Produk berpengaruh signifikan terhadap minat wisatawan berkunjung kembali. Artinya, semakin lengkap komponen produk wisata yang disediakan oleh pihak pengelola pada Objek Wisata Pantai Carocok Painan Kab Pesisir Selatan maka akan mempengaruhi minat wisatawan untuk berkunjung kembali. Yang termasuk pada produk wisata pada pantai Carocok Painan antara lain berbagai atraksi, fasilitas dan pelayanan yang disediakan serta accessilities (kemudahan pencapaian). Saat ini pengelola Pantai Carocok telah menyediakan berbagai atraksi untuk menarik wisatawan berupa wahana permainan air seperti banana boat, donat boat, flying boat, jetski dan snorkeling yang dipandu langsung oleh para pemandu yang berpengalaman. Pengelola juga mengadakan berbagai even berupa perlombaan-perlombaan dan festifal budaya yang diadakan di pantai Carocok. Untuk kenyamanan wisatawan pihak pengelola juga menyediakan berbagai fasilitas seperti gazebo dan pendopo untuk tempat beristirahat. Semakin lengkap fasilitas yang ditawarkan, maka akan memberikan kenyamanan bagi pengunjung dan juga dapat menambah nilai jualnya. Hal ini tentunya akan berdampak dengan semakin meningkatnya minat wisatawan untuk berkunjung kembali.

Sebuah produk atau jasa dikatakan menarik minat pelanggan apabila produk atau jasa tersebut dapat memberikan nilai yang lebih besar dari apa yang diharapkan oleh pelanggan. Produk atau jasa yang baik akan memiliki dampak positif terhadap minat berkunjung kembali.

Hal ini mengindikasikan produk yang mampu memberikan kepuasan bagi pengunjung adalah produk yang menunjukkan kualitas yang baik dan sesuai dengan apa yang diinginkan pengunjung. Jika kemampuan (hasil) produk yang dirasakan sesuai dengan harapan, maka akan menciptakan kepuasan bagi pengunjung sehingga pengunjung menjadi tertarik untuk berkunjung kembali.

Hal ini sesuai dengan penelitian yang dilakukan oleh Rambe (2014), yang menyatakan bahwa wahana permainan air Wonder Water Wold Waterpark CBD Poliania Medan sesuai dengan usia dan wahana permainan sangat beragam. Hal ini juga diperkuat dengan hasil penelitian yang dilakukan oleh Bachtiar (2016), dengan judul Pengaruh Strategi Bauran Pemasaran Terhadap Minat Berkunjung Kembali Di Objek Wisata Pantai Kabupaten Gunung Kidul (Study Kasus Pada Mahasiswa Strata 1 Fakultas Ekonomi Universitas Negeri Yogyakarta) dengan hasil produk berpengaruh positif dan signifikan terhadap minat berkunjung kembali. Ketika wisatawan merasa terpuaskan oleh sebuah produk jasa, wisatawan akan mencobanya lagi atau menggunakan kembali dan memberikan rekomendasi produk tersebut kepada orang lain.

\section{Pengaruh Harga terhadap Minat Berkunjung Kembali Secara Parsial \\ Harga tidak berpengaruh signifikan} terhadap minat berkunjung kembali. Artinya, harga pada Objek Wisata Pantai Carocok Painan Kab Pesisir Selatan tidak akan mempengaruhi minat berkunjung kembali. Seberapa besarpun harga yang ditetap oleh pihak pengelola, asalkan produk wisata yang ditawarkan sesuai dengan harapan dan manfaat harga tidak menjadi faktor penentu wisatawan dalam melakukan berkunjung kembali ke pantai Carocok Painan. Dapat disimpulkan bahwa harga tidak menjadi faktor penimbang bagi wisatawan untuk berkunjung kembali ke pantai Carocok Painan

Hal ini bertolak belakang dengan penelitian yang dilakukan Rambe (2014) dengan hasil bahwa harga berpengaruh positif tetapi tidak signifikan terhadap minat berkunjung kembali. Begitu juga penelitian yang dilakukan oleh Bactiar (2016), juga menemukan bahwa variabel harga berpengaruh positif signifikan terhadap minat berkunjung kembali.

\section{Pengaruh Promosi terhadap Minat Berkunjung Kembali Secara Parsial}

Promosi berpengaruh signifikan terhadap minat berkunjung kembali. Artinya, Promosi pada Objek Wisata Pantai Carocok Painan Kab Pesisir Selatan akan mempengaruhi minat berkunjung kembali. Iklan yang menarik mengenai wisata pantai Carocok Painan diberbagai media sosial atau baliho, juga informasi dari mulut ke mulut mengenai wisata pantai Carocok Painan akan mempengaruhi minat wisatawan berkunjung. Semakin sering promosi dilakukan oleh pemerintah daerah Pesisir Selatan maka minat berkunjung kembali wisatawan ke objek wisata Carocok akan semakin meningkat.

Hasil penelitian ini didukung oleh pendapat Laksana (2008: 133), yang menuturkan promosi adalah suatu komunikasi dari penjual dan pembeli yang berasal dari informasi informasi yang tepat yang bertujuan untuk merubah sikap dan tingkah laku pembeli, yang tadinya tidak mengenal menjadi mengenal sehingga menjadi pembeli dan tetap mengingat produk tersebut. Berdasarkan pengertian ini maka promosi merupakan aktivitas komunikasi yang berasal dari informasi yang tepat dan dapat berpengaruh terhadap minat berkunjung kembali. Wisatawan akan mengetahui suatu produk barang atau jasa lewar promosi yang dilakukan pihak pengelola produk barang atau jasa sehingga dapat memengaruhi minat berkunjung kembali

Hal ini sesuai dengan penelitian yang dilakukan oleh Bachtiar (2016), dengan hasil promosi berpengaruh positif dan signifikan terhadap minat berkunjung kembali Di Objek Wisata Pantai Kabupaten Gunung Kidul. Promosi yang menarik dan tepat sasaran akan menarik minat wisatawan baru untuk datang berkunjung ke pantai Carocok Painan. 


\section{Pengaruh Lokasi terhadap Minat Berkunjunng Kembali Secara Parsial}

Lokasi berpengaruh signifikan terhadap minat berkunjung kembali. Artinya, Lokasi pada Objek Wisata Pantai Carocok Painan Kab Pesisir Selatan akan mempengaruhi minat wisatawan untuk berkunjung kembali. Lokasi pantai Corocok membentang antara Painan dan kota Padang. Pantai ini berjarak $2 \mathrm{~km}$ dari pasar Painan dan sekitar 75 $\mathrm{km}$ atau sekitar 2 jam perjalanan dari kota Padang. Pantai Carocok ini juga dekat dengan beberapa objek wisata lainnya yang layak untuk dikunjungi seperti Pantai Kandang Jawi, Bukit Langkisau, Pulau Batu Kereta dan Pulau Cingkuak. Kondisi ini sangat menguntungkan bagi pihak pengelola objek wisata Pantai Carocok. Selain berkunjung ke pantai Carocok wisatawan juga dapat mengunjungi beberapa objek wisata lainnya yang ada di daerah Pesisir Selatan tersebut. Akses transportasi ke lokasi selain dapat menggunakan transportasi pribadi dan mobil carteran juga dapat ditempuh dengan menggunakan transportasi umum dari pasar Painan yang mengarah langsung ke lokasi wisata. Semakin baik akses jalan untuk menuju lokasi pantai, serta tersedianya transportasi yang layak di Carocok Painan maka minat wisatawan untuk berkunjung kembali akan semakin meningkat.

Hal ini sesuai dengan penelitian yang dilakukan oleh Bachtiar (2016), dengan hasil lokasi berpengaruh positif dan signifikan terhadap minat berkunjung kembali Di Objek Wisata Pantai Kabupaten Gunung Kidu. Hasil penelitian ini bertolak belakang dengan penelitian Rambe (2014), secara parsial variabel lokasi berpengaruh negatif dan tidak signifikan terhadap minat berkunjung kembali ke Wonder Water World Waterpark CBD Polinia Medan. Sedangkan menurut Tjiptono (2005), lokasi atau tempat seringkali ikut menentukan kesuksesan destinasi wisata, karena lokasi erat kaitannya dengan pasar potensial sebuah destinasi wisata. Sedangkan lokasi wisata pantai Carocok Painan memiliki lokasi yang strategis dan akses menuju objek wisata pantai Carocok Painan dapat dicapai dengan kendaraan umum.

\section{Pengaruh Orang terhadap Minat Berkunjung Kembali Secara Parsial \\ Variabel Orang pada Objek Wisata Pantai Carocok Painan Kab Pesisir Selatan tidak mempengaruhi minat berkunjung kembali wisatawan. Variabel orang dalam penelitian ini adalah orang-orang yang bertugas di pantai Carocok Painan seperti petugas pantai, penjaga tiket, penjaga parkir, pemandu wisata dan para pedagang. Saat ini mereka sudah bekerja sesuai dengan kompetensi dan bidangnya masing-masing. Mereka bersikap sopan, memberikan respon yang baik terhadap permasalahan yang dialami pengunjung, berkomunikasi dengan menggunakan bahasa yang baik dan benar serta mudah dimengerti serta}

memberikan informasi kepada pengunjung. Sikap mereka yang baik terhadap pengunjung merupakan cerminan dari budaya masyarakat disana yang ramah serta mendukung program pemerintah daerah untuk meningkatkan pendapatan daerah melalui objek wisata pantai Carocok. Sehingga dengan demikian variabel orang bukanlah menjadi faktor penentu wisatawan untuk berkunjung kembali ke objek wisata Carocok Painan.

Hal ini sesuai dengan penelitian yang dilakukan oleh Rambe (2014), dengan hasil bahwa orang tidak berpengaruh positif dan signifikan terhadap minat berkunjung kembali pada Wonders Water Word Waterpak CBD Polonia Medan. Sebaliknya hasil penelitian ini bertolak belakang dengan pendapat Lupiyoadi dan Hamdani (2009:75) dimana untuk mencapai kualitas terbaik maka karyawan harus dilatih untuk menyadari pentingnya pekerjaan mereka, yaitu memberikan konsumen kepuasan dalam memenuhi kebutuhannya. Dimana dengan diperolehnya kepuasan maka konsumen akan berminat menggunakan kembali produk/jasa yang ditawarkan.

Selain itu hasil penelitian ini juga bertolak belakang dengan penelitian Bachctiar (2016), dimana variabel orang secara parsial berpengaruh positif signifikan terhadap minat berkunjung kembali di objek wisata pantai Gunung Kidul. Kesimpulanya budaya sosial masyarakat dan petugas pantai Carocok Painan tidak memberi pengaruh berarti terhadap minat wisatawan untuk berkunjung kembali sehingga variable orang (people) bukanlah menjadi faktor penentu wisatawan untuk datang kembali.

\section{Pengaruh Proses terhadap Minat Berkunjung Kembali Secara Parsial}

Proses tidak berpengaruh signifikan terhadap minat berkunjung kembali. Artinya variabel Proses yang berkaitan dengan kecakapan dan ketanggapan petugas dalam melayani pengunjung, proses dalam pembelian tiket masuk, dan pelayanan yang baik dan cepat yang diberikan oleh petugas kepada pengunjung belum mampu mempengaruhi minat wisatawan untuk berkunjung kembali. Hal ini disebabkan karena wisatawan lebih mempertimbangkan ketersediaan berbagai produk dan fasilitas daripada proses atau prosedur yang mereka dapatkan pada objek wisata Carocok.

Hal ini bertentangaan dengan penelitian yang dilakukan oleh Rambe (2014), yang menunjukkan hasil bahwa proses berpengaruh positif dan tidak signifikan terhadap minat berkunjung kembali ke Wonders Water Word Waterpak CBD Polonia Medan. Semakin baik proses atau prosedur maka minat wisatawan berkunjung akan semakin meningkat. Penelitian ini sesuai dengan pendapat Zeithaml dan Bitner (2000) yang menyatakan bahwa prosedur yang mudah dan cepat akan membuat pelanggan merasa nyaman. 
Pengaruh Bukti Fisik terhadap Minat Berkunjung Kembali Secara Parsial

Bukti Fisik berpengaruh signifikan terhadap minat berkunjung kembali. Artinya, Bukti Fisik yang tersedia pada Objek Wisata Pantai Carocok Painan Kabupaten Pesisir Selatan, seperti lingkungan yang bersih dan nyaman, tersedianya mushola, toilet dan lahan parkir yang luas mampu mempengaruhi minat wisatawan untuk berkunjung kembali ke objek wisata pantai Carocok Painan.

Hal ini senada dengan penelitian yang dilakukan oleh Bachtiar (2016) yang menunjukkan hasil bahwa Bukti Fisik berpengaruh positif dan signifikan terhadap minat berkunjung kembali. Bukti fisik akan menambah daya tarik sebuah produk jasa. Karateristik intangible pada jasa menyebabkan pelanggan potensial tidak bisa menilai suatu jasa sebelum mengkonsumsinya (Tjiptono, 2005). Oleh sebab itu untuk meningkatkan minat konsumen terhadap suatu produk perlu ditambahkan bukti fisiknya. Semakin baik dan lengkap fasilitas yang disediakan oleh pihak pengelola objek wisata Carocok maka minat pengunjung untuk kembali pada objek wisata Carocok akan semakin tinggi.

Pengaruh Produk, Harga, Promosi, Lokasi, Orang, Proses, dan Bukti Fisik terhadap Minat Berkunjung Kembali Secara Simultan.

Produk, Harga, Promosi, Lokasi, Orang, Proses, dan Bukti Fisik secara bersama mempunyai pengaruh positif terhadap Minat Berkunjung Kembali. Hal ini sesuai dengan penelitian yang dilakukan oleh Bachtiar (2016), dengan hasil marketing mix berpengaruh positif dan signifikan terhadap minat berkunjung kembali pada Objek Wisata Pantai Kabupaten Gunung Kidul.

Tjiptono (2005) mengatakan bauran pemasaran merupakan seperangkat alat yang dapat digunakan pemasar untuk membentuk karateristik jasa yang ditawarkan kepada pelanggan. Hal ini menujukkan bahwa jika strategi bauran pemasaran diterapkan dengan baik maka akan memengaruhi minat berkunjung kembali.

Menurut Hellier et al (2003) minat beli ulang merupakan keputusan konsumen untuk melakukan pembelian kembali suatu produk atas jasa berdasarkan atas pengalaman dengan mengeluarkan biaya untuk memperoleh barang atau jasa, serta cenderung dilakukan secara berkala. Dengan kata lain, pengalaman yang diperoleh konsumen dari suatu produk atas jasa yang baik akan menimbulkan kesan positif yang menunjukkan bahwa konsumen mendapatkan apa yang konsumen butuhkan dan inginkan, sehingga konsumen akan melakukan pembelian ulang. Dengan demikian dapat disimpulkan bahwa semakin baik penerapan strategi marketing mix pada objek wisata pantai Carocok Painan antara lain produk wisata, harga, promosi, lokasi, orang, proses, dan bukti fisik maka minat wisatawan untuk berkunjung kembali akan semakin meningkat.

\section{Kesimpulan}

5.1 Kesimpulan

Berdasarkan hasil analisis tentang pengaruh marketing mix terhadap minat berkunjung kembali pada objek wisata Carocok maka dapat diambil kesimpulan sebagai berikut :

1. Marketing mix (7P) yang terdiri dari produk, harga, promosi, lokasi, proses, orang, dan bukti fisik secara simultan memiliki pengaruh positif dan signifikan terhadap minat berkunjung kembali pada pantai Carocok Painan. Namun secara parsial terdapat tiga variable yang tidak berpengaruh yaitu variabel harga, orang dan proses.

2. Variable yang memiliki pernguruh terbesar terhadap minat berkunjung kembali pada objek wisata Carocok Padang adalah variable bukti fisik, berupa fasilitas penunjang yang tersedia di lokasi objek wisata Carocok Painan seperti lingkungan yang bersih dan nyaman, tersedianya mushola, toilet dan lahan parkir yang luas.

\subsection{Saran}

Usulan perbaikan untuk meningkatkan minat berkunjung wisatawan ke pantai Carocok Painan adalah sebagai berikut :

a. Dinas Pariwisata Kabupaten Pesisir Selatan bekerja sama dengan pihak pengelola agar dapat mengelola objek wisata Carocok Painan lebih baik lagi dan profesional dengan menerapkan strategi pemasaran wisata yang baik, komprehensif dan terintegrasi pada semua aspek bauran pemasaran sehingga pantai Carocok ini nantinya dapat menjadi daerah tujuan wisata, baik bagi wisatawan domestik maupun mancanegara menyaingi Bali, Lombok dan Papua.

b. Produk berpengaruh signifikan terhadap minat berkunjung kembali pada objek wisata Carocok. Oleh sebab itu produk wisata yang ada pada lokasi objek wisata Carocok perlu dilengkapi dengan menambah variasi produk wisata seperti wahana permainan air, meningkatkan pelayanan kepada para wisatawan yang datang serta meningkatkan akses menuju lokasi dengan menyediakan sarana tranportasi umum yang cukup dan nyaman.

c. Promosi berpengaruh signifikan terhadap minat berkunjung kembali. Oleh sebab itu pihak pengelola sebaiknya melakukan promosi yang lebih gencar lagi diberbagai media termasuk dengan memanfaatkan media sosial, sehingga memudahkan pengunjung mendapatkan informasi yang dibutuhkan tentang objek wisata Carocok Painan. Selain itu berbagai event yang 
diadakan di lokasi wisata seperti perlombaanperlombaan dan festival budaya secara tidak langsung dapat menjadi daya tarik dan sarana promosi bagi wisatawan yang akan berkunjung ke objek wisata Carocok.

d. Lokasi berpengaruh signifikan terhadap minat berkunjung kembali. Oleh sebab itu agar memudahkan akses wisatawan berkunjung menuju lokasi wisata pantai Carocok diharapkan pemerintah Daerah Pesisir Selatan dapat membenahi sarana jalan serta menyediakan transportasi umum yang layak dan nyaman. Selain itu bagi wisatawan yang ingin menggunakan jalur laut dari Pelabuhan Muaro Padang menyusuri pulau-pulau pesisir pantai selatan pemerintah diharapkan dapat menyediakan kapal-kapal yang nyaman dan aman untuk disewakan kepada wisatawan.

e. Bukti Fisik berpengaruh signifikan terhadap minat wisatawan untuk berkunjung kembali. Oleh sebab itu pihak pengelola agar dapat menyediakan dan melengkapi berbagai fasilitas yang memadai serta menjaga kebersihan lingkungan di sekitar pantai, menyediakan toilet dan tempat-tempat ibadah yang bersih dan nyaman serta lahan parkir yang luas

\section{Daftar Pustaka}

Bachtiar, M. Latief. 2016.” Pengaruh Strategi Bauran Pemasaran Terhadap Minat Berkunjung Kembali di Objek Wisata Pantai Kabupaten Gunung Kidul”. Jurnal. Yogyakarta: Universitas Negeri Yogyakarta

Bilson, Simamora. 2001. Memenangkan Pasar dengan Pemasaran Efektif dan Profitabel. Edisi Pertama. Jakarta: Gramedia Pustaka Utama

Ghozali, Imam. 2009. Ekonometrika Teori, Konsep dan Aplikasi dengan Program SPSS 17. Semarang Badan Penerbit Universitas Diponegoro.

Hurriyati, Ratih. 2005. Bauran Pemasaran dan Loyalitas Konsumen. Bandung : Alfabeta

Hair, J. F, Black, W. C, Babin, B.J, Anderson, R. E., \& Tatham, R. L. 2006, "Multivariate data Analysis", Sixth Edition, New Jersey: Prentice Hall.

Laksana, Fajar. 2008. Manajemen Pemasaran. Yogyakarta: Graha Ilm

Lupiyoadi, Rambat dan Hamdani, A. 2009. Manajemen Pemasaran Jasa, Salemba 4, Jakarta.
Lupiyoadi, Rambat. 2013. Manajemen Pemasaran Jasa. Jakarta: Salemba Empat

Murwatiningsih. 2014. "Pengaruh Marketing Mix Terhadap Proses Keputusan Berkunjung ke Museum Rangga Warsita Semarang”. Jurnal. Semarang: Universitas Negeri Semarang

Nugroho, Bhuono Agung. 2005. Strategi Jitu Memilih Metode Statistik Penelitian dengan SPSS. Yogyakarta : Andi

Rambe, Oki Irawan (2014). Pengaruh bauran pemasaran jasa terhadap minat berkunjung kembali ke wonders water world waterpark cbd polonia medan. Skripsi. Program Studi Strata 1 Manajemen Departemen Manajemen Fakultas Ekonomi Universitas Sumatera Utara Medan

R, Basiya dan Rozak, Hasan Abdul. 2012. Kualitas Daya Tarik Wisata, Kepuasan, dan Niat Kunjungan Kembali Wisatawan Mancanegara di Jawa tengah. Jurnal Dinamika Kepariwisataan, Vol. XI No.2, p. $1-12$

Rukmi, Hendang Setyo, Hari Adianto, Martin. 2013. Identifikasi Variabel-Variabel Yang Mempengaruhi Minat Konsumen Dalam Pembelian Produk Handphone Samsung Dengan Menggunakan Structural Equation Modeling. Seminar Nasional Mesin Dan Industri (SNMI8) 2013 Riset Multidisiplin Untuk Menunjang Pengembangan Industri Nasional

Tjiptono, Fandy. 2005. Pemasaran Jasa, Malang: Bayumedia Publishing

Malang: Bayu Media

Purnama, M. Syakib Arsalan Citra, Murwatiningsih. 2014. "Pengaruh Marketing Mix Terhadap Proses Keputusan Berkunjung Ke Museum Ranggawarsita Semarang”. Jurnal. Semarang: Manajemen Fakultas Ekonomi Universitas Negeri Semarang

Zeithaml and Bitner. 2000. Service Marketing Integrating Customer Focus Across. The Firm, $3^{\text {rd }}$ edition. Boston. Mc Grow Hill/Irwi

(http://id.wikipedia.org/wiki/kabupaten_pesisir_sel atan). Diakses september 2016.

http://repository.usu.ac.id/handle/123456789/41418 